Abstracta Iranica Abstracta Iranica

Revue bibliographique pour le domaine irano-aryen

Volume 40-41 | 2019

Comptes rendus des publications de 2017-2018

\title{
Atefeh Seyed Mousavi. Narrative Illustration on Qajar Tilework in Shiraz
}

Yuka Kadoi

\section{Q OpenEdition}

1 Journals

\section{Electronic version}

URL: http://journals.openedition.org/abstractairanica/52126

DOI: 10.4000/abstractairanica.52126

ISBN: 1961-960X

ISSN: 1961-960X

Publisher:

CNRS (UMR 7528 Mondes iraniens et indiens), Éditions de l'IFRI

\section{Electronic reference}

Yuka Kadoi, "Atefeh Seyed Mousavi. Narrative Illustration on Qajar Tilework in Shiraz", Abstracta Iranica

[Online], Volume 40-41 | 2019, document 28, Online since 30 December 2019, connection on 17 April

2021. URL: http://journals.openedition.org/abstractairanica/52126 ; DOI: https://doi.org/10.4000/

abstractairanica. 52126

This text was automatically generated on 17 April 2021.

Tous droits réservés 


\title{
Atefeh Seyed Mousavi. Narrative Illustration on Qajar Tilework in Shiraz
}

\author{
Yuka Kadoi
}

\section{REFERENCES}

Atefeh Seyed Mousavi. Narrative Illustration on Qajar Tilework in Shiraz. Dortmund: Verlag für Orientkunde, 2018, Vol. 1, 335 p. (texts); Vol. 2, 268 p. (coloured images), ISBN: 9783936687463

1 This book is the forty-sixth volume of an interdisciplinary series in Islamic and Middle Eastern studies, Beiträge zur Kulturgeschichte des Islamischen Orients, published by Verlag für Orientkunde since 1949. Based on the author's doctoral dissertation, Narrative Illustration on Qajar Tilework in Shiraz, explores a group of illustrated tiles from nineteenth-century public and private buildings in Shiraz.

2 This unique artistic phenomenon has received little scholarly attention, compared with a growing number of publications on the Persian manuscript painting of the premodern period. Together with recent publications on related subjects (see Hadi Seif, Persian Painted Tile Work from the 18th and 19th Centuries: The Shiraz School, 2014), this book is another notable contribution to the Persian visual culture of the nineteenth century, when tilework played an integral role as another medium of narrative illustration.

3 This book consists of two volumes: Volume 1 is composed of the following six chapters: 1) Introduction; 2) Shiraz Tile Painting; 3) The Production of Tile Paintings; 4) Themes of Shiraz Tile Paintings; 5) Detailed Descriptions of the Surveyed Sites; and 6) Conclusion. The chapters are followed by a summary of themes and a bibliography. Volume 2 is a catalogue of the material collected during the author's extensive fieldwork in Shiraz. It contains a large number of photographs and ten maps, all published in colour.

4 The author has chosen 42 historical buildings (e.g., private residences, bazaars, bathes, gardens) in Shiraz with the variety of architectural style and tile decoration. Each 
catalogue entry documents a tiled building and analyses every detail of imagery, while identifying and classifying iconographic themes, as well as featuring craftsmen and their technological achievements. Among the notable chapters are Chapter 3 (pp. 57-68), which is based on interviews with the last generation of traditional craftsmen in Shiraz, and Chapter 4 (pp. 69-148), where various iconographic themes from some 700 tile paintings are classified according to religious and non-religious subjects.

5 Any researchers who are interested in the art of Qajar tilework will see Narrative Illustration on Qajar Tilework in Shiraz as an essential resource for understanding diverse aspects of Persian visual culture, both modern and pre-modern.

\section{AUTHORS}

\section{YUKA KADOI}

University of Vienna 